\title{
SINGING AS A STRATEGY TO ENHANCE THE ABILITY TO SPEAK FOR EARLY CHILDHOOD
}

\author{
Lidya Ndaru Kristyana \\ Junior High School Pius, Jalan Kapten Tendean No 16 Tegal, Indonesia
}

\author{
S. Suharto \\ Departmen of Music, Universitas Negeri Semarang, Kampus Sekaran, Indonesia \\ E-mail: suharto@mail.unnes.ac.id
}

Received: August 20, 2014. Revised: October 12, 2014. Accepted: November 7, 2014

\begin{abstract}
Song is one form of typical communication. Therefore, singing is implemented in this study as a strategy to enhance the ability to speak. This study is aimed to find out the role of songs in enhancing the ability to speak for children in early childhood. This classroom action research is conducted in two cycles, there are: planning, acting out and observing, as well as reflecting. Data were collected by conducting observation technique, documentation, and test. It is shown from the results of the study that the ability of children to speak is increasing for every cycle. In the beginning, the cycle reached by only $56 \%$ or in the average 51 , cycle I reached $60 \%$ with mean score 68,08 and cycle 2 reached $97 \%$ with the average score 83 . From the percentage, it is shown that results of cycle II has passed the minimum score for students in Kindergarten level. In other words, it is proven that singing has been successfully implemented as a strategy in teaching speaking. It has enhanced the ability of children to speak. It is suggested for teachers in Kindergarten level to implement singing as a teaching strategy to bridge the need to teach Kindergarten students to speak during the learning process.
\end{abstract}

Keywords: early childhood; singing; ability to speak

How to Cite: Kristyana, L. (2014). Singing as a Strategy to Enhance the Ability to Speak for Early Childhood. Harmonia: Journal of Arts Research and Education, 14(2), 123-130. doi:http:/ / dx.doi.org/10.15294/harmonia.v14i2.3293

\section{INTRODUCTION}

One of the basic aspects of development which is developed at a school for children in early childhood is language. The mastery of vocabulary is considerably influential towards the ability of children in using language to speak. Children who are learning vocabulary from early childhood will be relatively skillful in using language since the vocabulary itself has been planted inside the children's brain.

In its relation to language developmental aspect, speaking is one of crucial aspect in the development of basic ability in using language for children in early childhood. Speaking is mental-motor ability. Speaking is not only involving the coordination of different voice mechanism muscles, but it also has a mental aspect which is the ability to associate the produced sounds.

Several previous studies have shown that in every age level, passive vocabularies or "understanding" has largely been mastered by children rather than the active vocabularies or "speaking". As, for example, before children are capable to speak, children would have understood the general meaning of what is said by others. Children's understanding does not result from their understanding towards the meaning of the words uttered, but more as a result of their understanding towards the intonation of certain sounds, signs, or facial expression of the speakers. 
In line with the language, music in one of the medium to introduce universal language and can be used as a means of communication with others to express intention, ideas, thought, as well as feeling. Here, music has a similarity with language. Learning music is aiming to form verbal and non-verbal communication in order to achieve an optimal learning result. Besides, music also has a role as a creator to express ourselves as a whole as one of the necessities of human life.

The song is a written language which can be formed as a spoken language by adding music and tone in it. Music and tone need to be added to the song in order to beautify the lyrics, so that it will be able to be sung and heard. The song can be heard if it is sung. Singing is a kind of activity which is always done by children. Almost all children who enter early childhood education will be taught to sing. Children's songs can be identified from the perspective of musicality, lyrics, as well as words contained within the song, and also from the perspective of children as the recipient of the song.

The song is one of typical communication form. The distinctness appears in its characteristics, which are: one-way communication (the song does not require a direct dialogue with the listener), rhythmical, having a dense language, and containing an aesthetic value. A song comprises two forms of expression, which are musical expression in a form of song and rhythm and linguistic expression in a form of lyric.

Language within the song is formulated through alliteration, assonance, rhyme, and rhythm. This will create happiness for children. Happiness can relieve children's anxiety and foster children's self-awareness to learn. This is an ideal condition to learn since the obstacles can be eliminated and information can be easily enjoyed and absorbed (Nurgiyantoro, 2005, p. 98-101).

Through the language of a song, children will gain high sensitivity towards the sounds of language and they will realize the functions and power of words on the next stage (Nurgiyantoro, 2005, p.
101). In the language of a song, there is a difference between the languages used as the lyric of an adult song with the language used as the lyric of a children's song. Differences in the type of language used in the songs are based on the purpose of to whom a song is intended to be given for. Adult songs, for instance, usually use a series of vocabulary related to love, and broken heart. Whereas children's songs are created by using simple vocabularies related to children's world and experience and how to see those experiences from the meaningful perspective (Nurgiyantoro, 2005 , p. 353). The children's world and experiences are closely related to the things around childhood, such as: parents, teachers, friends, animals, and environment.

Children's songs have a central role in children's growth and development which are as a medium of self expression and education in order to improve the quality of human life. A good children's song with a decent lyric and in line with the development of children will give a positive contribution in the establishment of children's character from early childhood. A good children's song is a song which contains valuable lessons delivered through the lyrics of a song.

The development of children's language is the increasing ability of children's communication tool in written, spoken, and/or sign language. According to Gunarsa (1995, p. 11), the early childhood period is also called as the pre - school period for children ages 2-6 years old. Characteristics of this period are the development of language and thought. Language is considered to be essential for pre-school children since language is considered as the most effective communication tool to start an initial communication. Along with the communication which happens at school and neighborhood, children's language is also developed and children can receive new vocabularies.

Capability means having abilities; skills; power (Depdiknas, 2005, p. 22). Speaking can be understood as delivery of intent (ideas, thought, or heart feeling) 
of one person to another person using spoken language, so that the intention of the speaker can be understood by the listener (Depdikbud, 1984, p. 7). The ability to speak needs to be developed since people need a considerable number of vocabularies to deliver their purpose in communication. An earlier argument was put forward by Suhartono $(2005$, p. 138) by delivering that in order to develop the ability to speak, there several aspects which need to be done, there are: stimulating the intention to speak, practicing to combine the sounds of language, enriching the vocabularies, knowing and understanding of simple sentences, as well as knowing about the symbol of writing.

Apart from the aspects which had been mentioned previously, there are several other criteria within the children's ability to speak. According to Syamsul (2009, p. 191), one of the criteria is self-centered speaking (egocentric) and speaking, which is placing the center on others (socialization). Here, we focus on socialization, since talking to others needs an ability to understand vocabularies and express ideas. Therefore, singing as a strategy to teaching speaking for early childhood is essential. By singing, children will be able to express themselves freely and purposefully conveyed. Meanwhile, singing is an activity to produce voice (sounds) with rhythmical lyrics. Thus, singing as a strategy is a kind of effort to empower all speaking aspects (intrinsic and extrinsic) to achieve the intended purpose which is to enhance the ability to speak. In addition to the aspects of speaking are intrinsic aspect comprises articulation, rhythm, and intonation, while extrinsic aspect encompasses the meaning of a song, and the aesthetic experience of the singer.

Gordon (2011) is a music psychologist who states that in the process of introducing children to music is to learn music which has the same stage as they learn to speak. From the explanation from Gordon, we can say that parents as well as teachers have a significant role to guide children to understand music and the languages used in the music. It is because by learning language, we will able to learn other things which we didn't know before. Music gives children a rare opportunity to create new things and be eloquent in thinking. They respond the music in unique ways by listening or moving their body to follow the music, or creating a new song by changing the lyric of a given song. Meanwhile, Schellenbergh (2003) relates music with a series of cognitive skill. He argues that the improvement of children's ability after the implementation of singing as a strategy in teaching speaking is closely related to the period of focused attention, memory, and concentration which is needed while listening to music, playing music, or creating music.

Kindergarten is the best place for children to play, sing, draw, dance, and study with other children of their age. Kindergarten is seen as a place for children to train their creativity by using several tools, so that children can develop their activity and creativity. Suharto (2000, p. 400) explains that one of the functions in giving music lessons at school is to act as the aid to optimize the right brain of children, so that their the feeling and imagination can be balanced with the development of logic which is operated by their left brain. Therefore, the strategy of singing is considered to be enough to contribute to the ability of children in speaking. Besides singing is considered to be fun, children can also learn something by singing. For instance, children may learn to understand lyrics, intonation, articulation, meanings and the kinds of vocabularies. Moreover, by singing, children are trained to memorize and challenged to produce sentences well.

Language is an essential factor to be mastered by children since the development of intellectuality of a child is closely related to language. When children are singing songs, they are indirectly and subconsciously also learning the language. The words have an important role since it draws the content or meanings of a song. Children's songs also serve as educational music which concerns to the effect of music 
towards the growth and development of children (Tyasrinestu, 2013). In addition to this, she argues that children's song which is integrated in the lesson makes children to understand the lesson more since it will be sung repeatedly and remembered for all time. Through her study, it is revealed that the characteristics of Indonesian children's songs ought to be adjusted to the children's growth and development.

The Early childhood period is also called as a golden age period. It is characterized by the rapid changes in physical, intellectual, cognitive, and emotional development. This is in line with the development of the brain which has reached up to $50 \%$. Therefore, in this period, children are able to accept any kinds of input from their neighborhood quickly, including language and music. Music is not only pleasant but also appropriate to the child's condition and soul which are cheerful and keen on playing. That is why music can be easily accepted by children. For that reason, learning through singing the lyrics of a song will be able to develop the children's language quickly as well.

The influence of environment, including a mother, also determines the development of children's language since a mother is relatively the closest person to the children who spend most of the time together with the children. As a result, almost all of experiences which are related to music and language, such as: pitch, tempo, rhythm, tone will influence the ability of children in producing language and playing music (Bergeson \& Trehub, 2002, p. 72). Cyrille \& Mireille (2004, p. 341) reveal their results of study by arguing that the intensive music training can influence the children's perception of pitch contour in spoken language. It means the habituation of music or singing through musical training can influence the ability of children to speak.

Thus, music is capable of influencing the ability of children at an early age since it is able to develop the children's intelligence, language proficiency, coordination skills, as well as children's ima- gination. With the presence of music lesson, children may build up their talents as well as for early age children to grow based on their talents and interests in the field of language, communication, physic, emotion, cognition, knowledge, social, and aesthetic. It means the ability to play music, mainly to sing, is also contributing to the language ability of children based on the stages of language development of the children themselves. As it was mentioned earlier, in the period of golden age, the music and language proficiency will be very quick to be developed. The music itself is a pleasant lesson which is highly preferred by the children because of its playful nature and fun aspects. Learning to sing a song which contains the aspects of language is believed to be able to enhance the ability of children to speak. Precisely, children will be able to speak with a clear intonation of utterances as well as many vocabularies through the lyrics of a song which is frequently sung.

\section{METHOD}

This study is conducted using classroom action research which is done by planning, doing, and reflecting the collaborative and participatory action with the aim of improving the performance of teachers, so that students' learning outcomes can be improved. This study is divided into two cycles, which are cycle I and cycle II, which is initiated by the stage of precycle. Cycle I and cycle II consist of three meetings. In the first and second meetings, the learning process is held. While in the third meeting, the assessment and evaluation were conducted. The procedure of this classroom action research comprises planning, classroom implementation, observation, analysis, and reflection.

Further, this study is carried out using both qualitative and quantitative approaches. Qualitative is implemented here to analyze the data which cannot be measured by numbers. This typical of data is usually obtained in a form of cases, so that the data will require further elaboration 
through description. In this research, the sources of data comprise: 1) the location of the research (research site); 2) a brief history of the school; 3) facilities and infrastructure; 4) Programs of the Kindergarten; 5) number of students; 6 ) the teachers. Quantitative is used to analyze the data which is measured by numbers. The data collected in this study are taken in the form of assessment results through the children's interests in following the singing lesson and the results of the study is taken from the written test of students.

In this research study is conducted in Pertiwi Kindergarten, Tegal. Data is collected by using documentation technique, observation, and test. Documentation technique is a data collection technique which is done by collecting documents which are related to students and the school. Observation technique is a kind of direct observation conducted in the research site and relates closely to the phenomenon happened on the research site. There are several aspects which are observed here. Among them are attentions, interaction between students and the teacher, as well as positive response. The test is a series of question used to measure skills, knowledge, attitudes, abilities, and aptitudes which are had by individuals or groups. Furthermore, instrument of research can be developed during the preparation of research proposals or after the research is accepted and implemented. This study is conducted to find out the results of study after the implementation of singing as a strategy in teaching speaking. The test itself is implemented by encompassing several aspects in speaking ability, there are: expressing ideas, mastering vocabularies, making sentences, and pronouncing sen- tences.

\section{RESULTS AND DISCUSSION}

\section{Singing as a Strategy to Teach Speaking}

The results of this study comprise the stage of pre-cycle, cycle I, and cycle II. A pre - cycle test was conducted to find out how active and how far the ability of children in speaking before the strategy was implemented in classroom teaching and learning. The pre-cycle data was collected after the pre test related to the results of the students' learning was held. Pre test encompasses the ability to express ideas, vocabulary mastery, the ability to create sentences and the ability to pronounce sentences, while the assessment of interest was taken from the observation of children's behavior during the learning process.

In the beginning of the pre-cycle stage, the mean of students' learning outcomes only reaches the number of 51 or in the category of less able, whereas the results of the observation of interests show the negative behavior is still dominant at this stage. Children are still indifferent to the learning process $62.5 \%$, children talk to themselves or chatting with others $83 \%$ and children still have trouble following the teaching and learning process $83 \%$. After pre-cycle was conducted, cycle I started to be implemented using the strategy of singing to teach speaking. Results show that the average of learning outcomes is increased up to 68.08 or in the category of adequate, whereas the direct observation starts to show the positive attitudes of students in facing the learning material. In detail, the percentage can be explained, as follows: students who pay attention

Table 1. The Improved Learning Outcomes for Each Cycle

\begin{tabular}{cccccccc}
\hline \multirow{2}{*}{ No } & Range of & \multicolumn{3}{c}{ Number of Students } & \multicolumn{3}{c}{ Percentage } \\
\cline { 3 - 8 } & Scores & Pre-cycle & Cycle I & Cycle II & Pre-cycle & Cycle I & Cycle II \\
\hline 1. & $86-100$ & 0 & 0 & 5 & $0 \%$ & $0 \%$ & $24 \%$ \\
2. & $71-85$ & 0 & 13 & 18 & $0 \%$ & $60 \%$ & $73 \%$ \\
3. & $56-70$ & 11 & 9 & 1 & $56 \%$ & $35 \%$ & $3 \%$ \\
4. & $\leq 55$ & 13 & 2 & 0 & $44 \%$ & $5 \%$ & $0 \%$ \\
\hline
\end{tabular}


to the teacher while explaining the song $62.5 \%$, students who following the way to sing properly $75 \%$, children who show positive response and actively participated $83 \%$. Those results show that the implementation of the cycle I has not yet optimum. It can be seen from the average of the score which is still under the minimum standard score. It needs to be noted that the minimum standard score for Kindergarten students in speaking is 80 , while the result in the cycle I shows that the average score of students is 68.08. As a consequence, cycle II was conducted in order to achieve higher results. It emphasized on the ability to pronounce sentences fluently. Researchers gave motivation for students to be more active and brave in delivering ideas. As a result, the ability of students to speak is increased up to 83 in average. It belongs to the category of satisfying.

The results of this study indicate that singing has a good impact in the development of children's language. According to Globe (1987), music has several similarities to language. Learning music can help to form the verbal and non-verbal communication in order to achieve an optimum learning effort. Moreover, besides helping people to express feeling, music can also act as a creator to show ourselves as a whole as one of the necessities of human life. Specifically for children, by singing, they can receive a kind of language game which is presented in the form of music and rhythm, so that the children can be more interested in learning language and speaking by using singing as the strategy. Results shown in this study is in line with what have been delivered before by Mitchell (2003, p. 73). Mitchell delivers that the game of languages can be achieved from several means of alliteration, assonance, rhyme, and rhythm which can make children to be happy and enjoy as well as eliminate the children's anxiety and raising children's awareness to learn. Therefore, if the previous arguments are combined, it can be concluded, as follows: singing has a significant role in its relation to the language, if a child is able to under- stand the vocabularies, then the ability of children in speaking is also increased. In addition to this, if children are capable to use languages, accordingly, they will use the language to talk to others. From the languages of songs, children gain high sensitivity towards the sounds of language and in the next stage of their age; children will realize the functions and the power of words. A researcher, Wolf (1979), did an experiment by gathering children in early childhood to see whether the habit of playing music to children will give positive impacts towards the children's motor skill. Results showed that children's familiarity towards music which had been routinely given before we're able to fill the empty spaces of social and emotional aspects of children. Music is proven to be able to increase the confidence of children when they have to face a large room with a considerable number of people in it, including their friends and teachers who were originally perceived as a threat. In the journal entitled Harmonia, Joseph (2003, p. 77) states that music is given at school as a tool to optimize the function of the right brain in order to balance the feeling and imagination had by human to the development of logic in the left brain. However, in the implementation of this idea for children, the music materials are still needed to be adjusted to the guidelines of appreciation and creation education. In line with Joseph, the result of this study also reflects the conception delivered by him. It can be seen from the ability of students in integrating the rhythm well. It can be seen from the creativity of an individual in doing the school tasks, such as: drawing or matching pictures. In doing those tasks, children are able to illustrate the pictures with an interesting idea.

During the process of teaching and learning, the presence of singing as one of the strategy has a quite essential meaning. During the process, the vagueness of the presented material can be helped by presenting a song as the medium in exploring the materials. The complexity of the materials which ought to be given to students 
can be simplified by using songs. The strategy of singing can represent of what cannot be explained by teachers using certain words or sentences. This strategy can make the materials easier to be understood.

Teaching four and five-years-old students to speak who are generally unable to express ideas and master the vocabularies need to stress out the importance to develop the students' ability in creating sentences so that the children can deliver the sentences fluently. In this regards, the use of singing as a strategy to teach speaking is considered to be appropriate. Giving children a musical stimulus, can help them to synchronize ideas, vocabularies, and utterance while singing. Hence, again, the use if singing as a strategy is seen to be appropriate to be given to students since it combines music and language as well as an ability to speak.

The use of singing as a strategy in teaching the ability to speak is considered to be ideal to be used in order to ease the teacher in explaining the learning materials. The easiness obtained from the use of strategy is the teachers can develop the aspects of children with language ability. Besides, teachers will also able to build a positive communication to children. The most essential role of this strategy is to grow the children's interests and motivation towards the learning activities. In other words, singing can stimulate children's ability to speak. Music which is played by various instruments, such as guitar, is also considered to be interesting for children. It opens an opportunity for children to sing happily according to the rhythm of the music, so that the abilities of students to sing and speak are increased. Finally, it can be underlined that, the use of singing as a strategy can result in positive outcomes if it is implemented appropriately.

\section{CONCLUSION}

From the research conducted in Pertiwi Kindergarten, it is proven that the implementation of singing as a strategy to teach speaking for students has been suc- cessful in increasing the ability of children to speak. The success of the strategy implementation can be identified by the increase of students' score, from the average score of 68.08 in the cycle I to 83 in cycle II.

The increase in the language ability, especially in speaking, is caused by the languages of songs they sing every time. From the lyrics of the childen's songs, children gain high sensitivity towards the sounds of language and in the next stage of their age; children will realize the functions and the power of words. Besides, By singing, children will be able to express themselves freely and purposefully conveyed. Meanwhile, singing is an activity to produce voice (sounds) with rhythmic lyrics. Thus, singing as a strategy is a kind of effort to empower all speaking aspects (intrinsic and extrinsic) to achieve the intended purpose which is to enhance the ability to speak. In addition to the aspects of speaking are intrinsic aspect comprises articulation, rhythm, and intonation, while extrinsic aspect encompasses the meaning of a song and the aesthetic experience of the singer.

The teachers of the early childhood need to give more attention to the children, especially when they are singing. They should be able to guide and develop a child's ability in singing and producing words. Besides, parents should choose the songs carefully. The songs which are sung by children ought to be appropriate to the children's character, so that, the development of children's language can be welldirected.

\section{REFERENCES}

Arostiyani, D. (2013). Pemanfaatan Lagu Anak-anak sebagai Media Pendidikan Karakter di Taman Kanak-kanak Aisyiyah Desa Linggapura Kecamatan Tonjong, Brebes. Thesis. Semarang: Universitas Negeri Semarang.

Arum, J. R. (2014). Upaya Meningkatkan Minat dan Hasil Belajar Bernyanyi Melalui Penggunaan Media Alat Musik Keyboard Pada Siswa Tk H.J. Nartini 
Semarang. Thesis. Semarang: Universitas Negeri Semarang.

Banoe, P. (2003). Kamus Musik. Yogyakarta: Kanisius.

Barbara, A. W. \& Caroll, S. (2008). Pendidikan Anak Usia Dini. Jakarta: PT Indeks.

Bateson, G. (1972). Steps to An Ecology of Mind. New York: Ballatine.

Bergeson, T., \& Trehub, S. (2002). Absolute Pitch and Tempo In Mothers' Songs to Infants. Psychological Science, 13(1), 72-75.

Cyrille, M. \& Mireille, B. (2004). The Music of Speech: Music Training Facilitates Pitch Processing In Both Music and Language. Psychophysiology, 41(3), 341-349.

Djamarah, S. B. (2011). Psikologi Belajar. Jakarta: Rineka Cipta.

Djawanai, S. (2009). Telaah Bahasa, Telaah Manusia. Pidato Pengukuhan Jabatan Guru Besar pada FIB UGM 4 November 2009. Yogyakarta.

Gordon, E. E. (2011). Early childhood music abuse: Misdeeds and Neglect. Visions of Research in Music Education. 17. Retrieved from http://usr.rider. edu/ vrme/v17n1/visions/article.

Herminingrum, E. (2013). Meningkatkan Aktivitas dan Hasil Belajar Apresiasi Musik Nusantara Melalui Penggunaan Lagu Model Pada Siswa Kelas VIII A SMP Negeri 1 Pangkah, Kabupaten Tegal. Thesis. Semarang: Universitas Negeri Semarang.

Jinyoung, K. (2000). Children's Pitch Matching, Vocal Range, and Developmentally Appropriate Practice. Journal of Research in Childhood Education, 14(2), 156-165.

Kusumah, W. (2010). Mengenal Penelitian Tindakan Kelas. Jakarta: PT Indeks.

Masidjo, I. (1995). Penilaian Pencapaian Hasil Belajar Siswa di Sekolah. Yogyakarta: Penerbit Kanisius.

Morin, E. (2005). Tujuh Materi Penting bagi Dunia Pendidikan. Yogyakarta: Penerbit Kanisius.

Nurgiyantoro, B. (2005). Sastra Anak: Pengantar Pemahaman Dunia Anak. Yogyakarta: Gadjah Mada University
Press.

Papalia, D. E. (2008). Human Development Psikologi Perkembangan. Jakarta: Penerbit Kencana.

Purwanto. (2013). Evaluasi Hasil Belajar. Yogyakarta: Pustaka Pelajar.

Rachmi, T. (2010). Keterampilan Musik dan Tari. Jakarta: Penerbit Universitas Terbuka.

Scarlett. W. G. (1987). When is a song a song? The development of singing in early childhood. Early Childhood Education Journal, 14(3), 30-31.

Schellenberg, E. G. (2003). Does Exposure to Music Have Beneficial Side-effects? In I. Peretz \& R. J. Z. (Eds.). The Cognitive Neuroscience of Music. (430448). Oxford, UK: Oxford University Press.

Subiantoro. (2009). Penelitian Tindakan Kelas. Semarang: Universitas Diponegoro.

Suharto. (2000). Peran Seni dalam Pengoptimalan Fungsi Otak, Lingua Artistika. 23(3), 400-409.

Suharto. (2006). Permasalahan Musikal Lingual dalam Penerjemahan Lirik Lagu. Harmonia: Journal of Arts Research and Education, 7(2), 120-129.

Syamsul, Y. L. N. (2009). Psikologi Perkembangan Anak Dan Remaja. Bandung: PT Remaja Rosda Karya Suryabrata.

Tillman, D. (2004). Living Values Activities For Children. Jakarta: Grasindo.

Tyasrinestu, F. (2013). Bahasa Lagu Anak Berbahasa Indonesia. Yogyakarta: Ringkasan Disertasi UGM.

Wassum, S. (1979). Elementary school children's vocal range. Journal of Research in Music Education, 27(2), 214-226.

Widianawati, N. (2011). Pengaruh Pembelajaran Gerak dan Lagu dalam Meningkatkan Kecerdasan Musikal dan Kecerdasan Kinestetika Anak Usia Dini. Inovete. (2), 220-228.

Wozniak, R. H. (1987). Developmental method, zone of development, and theories of the environment. In L. S. Liben (Ed.), Development and learning: Conflict or congruence? (pp. 225-235). 